METHODOLOGICAL ISSUES IN SOCIAL SURVEYS 
General Editors: J. Maxwell Atkinson, Donald R. Harris, R. M. Hartwell

Oxford Socio-Legal Studies is a series of books and conference proceedings published by the Centre for Socio-Legal Studies, Wolfson College, Oxford (a research unit of the Social Science Research Council). The series is concerned generally with the relationship between law and society, and is designed to reflect the increasing interest in this field of lawyers, social scientists and historians.

\section{Already published}

J. Maxwell Atkinson and Paul Drew: ORDER IN COURT: THE ORGANIZATION OF VERBAL INTERACTION IN JUDICIAL SETTINGS

Ross Cranston: REGULATING BUSINESS: LAW AND CONSUMER AGENCIES

David P. Farrington, Keith Hawkins and Sally M. Lloyd-Bostock (editors): PSYCHOLOGY, LAW AND LEGAL PROCESSES

Forthcoming titles

Paul Fenn and Yvonne Brittan: THE ECONOMICS OF ILLNESS AND INJURY

Donald R. Harris, Mavis Maclean, Hazel Genn and others: COMPENSATION AND SUPPORT FOR ILLNESS AND INJURY

Keith Hawkins: POLLUTION, LAW ANDSOCIAL CONTROL:THEUSEOF DISCRETION IN A REGULATORY AGENCY

Terry Ison: NO-FAULT ACCIDENT COMPENSATION IN PRACTICE:

THE EXPERIENCE OF CANADA AND NEW ZEALAND

Otto Kahn-Freund: LABOUR LAW AND POLITICS IN THE WEIMAR REPUBLIC

Sally M.Lloyd-Bostock: PSYCHOLOGY AND THE LAW: RESEARCH AND PRACTICE

Mavis Maclean and Hazel Genn: METHODOLOGICAL ISSUES IN SOCIAL SURVEYS

Doreen J. McBarnet: CONVICTION: THE LAW, THE STATE AND THE CONSTRUCTION OF JUSTICE

Alan Paterson: THE LAW LORDS

Genevra Richardson, Anthony Ogus, Paul Burrows: POLICING POLLUTION:

A STUDY OF REGULATION AND ENFORCEMENT

Gerry Rubin and David Sugarman: LAW, ECONOMY AND SOCIETY 1700-1918 


\section{METHODOLOGICAL ISSUES IN SOCIAL SURVEYS}

Mavis Maclean and Hazel Genn

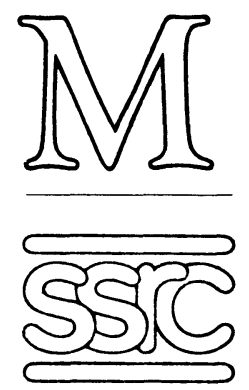


(C) Social Science Research Council 1979

Softcover reprint of the hardcover 1st edition 1979

All rights reserved. No part of this publication may be reproduced or transmitted, in any form or by any means, without permission

First published 1979 by THE MACMILLAN PRESS LTD

London and Basingstoke Associated companies in Delhi Dublin Hong Kong Johannesburg Lagos Melbourne New York Singapore Tokyo

Typeset in Great Britain at The Pitman Press, Bath and printed by Billing and Sons Ltd Guildford, London and Worcester

British Library Cataloguing in Publication Data

Maclean, Mavis Methodological issues in social surveys (Oxford socio-legal studies)

1. Social surveys-Decision making I. Title II. Genn, Hazel III. Series $309^{\prime} .07^{\prime} 23$ HN29

ISBN 978-1-349-04062-9 ISBN 978-1-349-04060-5 (eBook) DOI 10.1007/978-1-349-04060-5

This book is sold subject to the standard conditions of the Net Book Agreement 


\section{Contents}

Preface vii

1 INTRODUCTION 1

2 ALTERNATIVE SOURCES OF DATA 6

3 DEVELOPING A SCREENING INSTRUMENT 21

Defining a Concept and Choosing an Indicator Testing for Validity

4 PROXY RESPONSE IN SOCIAL SURVEYS 58

5 THE CHOICE OF A METHOD OF DATA COLLECTION 78

6 SAMPLE DESIGN 99

$\begin{array}{ll}\text { Index } & 117\end{array}$ 


\section{Preface}

Large-scale survey work involves a continuous process of decision-making, with a common theme - the conflict between rigorous academic standards and the allocation of scarce resources. It is difficult to identify a critical path for the process, as so many decisions are interdependent, have to be considered simultaneously, and have important implications for the remaining decisions. The situation is often made even more complex in large-scale work by the different perspectives and priorities held by individual members of a project group, who are unlikely in the social science research setting to have had broad experience of large-scale empirical work. The guidance available in the existing literature falls into three groups: firstly, textbook coverage, which may be comprehensive in scope but tends to be lacking in depth on specific issues; secondly, specialist articles, where the conclusions reached depend heavily on the specific circumstances of the project; and thirdly, the methodological appendices of other projects which are inevitably concerned to vindicate the approach taken and perhaps reluctant to reveal the problems involved, or the less academically respectable constraints experienced. This collection of papers does not purport to be a survey textbook, or a project-specific methodological apologia. Instead we hope to offer frank discussion of some examples of the issues to be faced during the course of a large-scale project which are of general interest to those planning work on this scale.

The papers result from work completed between 1975 and 1978 at the SSRC Centre for Socio-Legal Studies, Wolfson College, Oxford. Mavis Maclean and Hazel Genn took continuing responsibility for the large-scale survey, under the direction of Donald Harris, with support from Sally Lloyd-Bostock who wrote part of Chapter 3 (Testing for Validity), and from Yvonne Brittan, Sandra Burman, Karen Clarke, Peter Corfield, Keith Hawkins, Jenny Phillips and Genevra 
viii

Richardson. Douglas Wood of Social and Community Planning Research made a major contribution to Chapter 6 . The research also benefited considerably from consultation with John Utting, Graham Kalton and Seymour Sudman. Philip Whittall contributed to the statistical analyses. 